\title{
Pengaruh Current Ratio, Return On Assets, dan Nilai Tukar Rupiah terhadap Harga Saham Farmasi
}

\author{
Neni Nur'aeni' ${ }^{1}$, Gusganda Suria Manda ${ }^{2}$ \\ ${ }^{1,2}$ Universitas Singaperbangsa Karawang \\ e-mail: ${ }^{1}$ neni.nuraeni16193@student.unsika.ac.id, ${ }^{2}$ gusganda.suriamanda@fe.unsika.ac.id
}

\begin{tabular}{ccc}
\hline Diterima & Direvisi & Disetujui \\
$14-10-2020$ & $21-12-2020$ & $08-03-2021$ \\
\hline
\end{tabular}

\begin{abstract}
Abstrak - Penelitian ini dilakukan pada perusahaan manufaktur sektor industri barang konsumsi dan fokus penelitian ini adalah sub sektor perusahaan farmasi yang terdaftar di Bursa Efek Indonesia (BEI) tahun 2014-2018. Jumlah populasi dalam penelitian ini sebanyak 11 perusahaan, penelitian ini menggunakan metode purposive sampling lalu berdasarkan kriteria yang telah ditentukan diperoleh 8 sampel perusahaan yang akan di uji dalam penelitian ini. Jenis data dalam penelitian ini adalah data kuantitatif. Sumber data yang digunakan adalah data sekunder yang bersumber dari situs resmi BEI, BI dan perusahaan masing-masing. Hasil penelitian ini menunjukkan bahwa secara parsial hanya Current Ratio dan Return On Assets yang memiliki pengaruh signifikan terhadap harga saham. Namun secara simultan Current Ratio, Return On Assets dan Nilai Tukar Rupiah mempunyai pengaruh yang signifikan terhadap Harga Saham.
\end{abstract}

Kata Kunci : current ratio, return on assets, nilai tukar rupiah, harga saham.

Abstract - This research was conducted at manufacturing companies in the consumer goods industry sector. This research focus is on the pharmaceutical company sector listed on the Indonesia Stock Exchange (IDX) in 2014 2018. The population in this study was 11 companies. This study used a purposive sampling method, and then, based on the predetermined CRiteria, obtained eight samples of companies that will be tested in this study. The type of data in this research is quantitative data. The data source used is secondary data sourced from the official website of the IDX, BI, and their respective companies. This study's results indicate that only the Current Ratio and Return On Assets partially have a significant effect on stock prices. However, simultaneously Current Ratio, Return On Assets, and Rupiah Exchange Rate have a significant influence on stock prices.

Keywords : current ratio, return on assets, rupiah exchange rate, stock price

\section{PENDAHULUAN}

Industri manufaktur merupakan salah satu penyokong perekonomian nasional yang memberikan kontribusi cukup penting pada pertumbuhan ekonomi di Indonesia. Perusahaan farmasi adalah sub dari sektor industri barang konsumsi yang memiliki peranan penting dalam hal kesehatan khususnya obatobatan. Perekonomian di suatu Negara salah satunya dipengaruhi oleh peran besar pasar modal. Harga saham di pasar modal menunjukkan keberhasilan perusahaan dalam mengelola dan meningkatkan kekayaan perusahaan untuk menjadi tolak ukur para investor berinvestasi.

Pada tahun 2015 Sejumlah pihak menilai kondisi perekonomian telah memasuki masa krisis seperti yang terjadi di tahun 1998 akibat terus melemahnya nilai tukar rupiah. Jatuhnya pasar modal dan nilai tukar rupiah lebih dipengaruhi oleh faktor eksternal daripada internal. Dunia menghadapi tantangan bersama mulai dari krisis utang Yunani, ketidakpastian jadwal normalisasi suku bunga Fed hingga currency wars menyusul keputusan China mendevaluasi yuan.

Tingkat inflasi yang tinggi pada kuartal 12015 yaitu sebesar $0,17 \%$ membuat daya beli masyarakat menurun, dan secara tidak langsung tingkat inflasi ini mempengaruhi kinerja emiten sektor farmasi, diikuti dengan nilai tukar rupiah yang terus melemah hingga Rp 13.121 per dollar AS. Pelambatan volume penjualan dan pelemahan rupiah menjadi penyebab pendapatan rata-rata melambat menjadi $10 \%$ kondisi itu membuat produksi meningkat dan menekan margin laba. Depresiasi rupiah dan dampak inflasi berpotensi menggerus daya beli masyarakat, terutama produsen obat.

Perusahaan farmasi di Indonesia tidak lepas dari dampak akan pelemahan rupiah, apalagi nilai tukar rupiah sepanjang separuh pertama tahun 2015 ini turun tajam. Semakin rendah nilai tukar kurs rupiah, kinerja perusahaan farmasi akan terus semakin tertekan karena $90 \%$ bahan baku farmasi 
merupakan produk impor dan porsi biaya bahan bakunya sebesar $75 \%$ terhadap total biaya produksi produk farmasi.

Ketika rupiah melemah tentunya pembelian bahan baku menjadi mahal, sehingga biaya produksi pun menjadi besar, salah satu cara mengatasinya adalah dengan menaikkan harga jual. Akan tetapi itu membuat daya beli masyarakat menjadi menurun karena harga produk yang mahal dan bisa berpengaruh terhadap laba perusahaan. Sehingga hal itu juga mengakibatkan harga saham perusahaan farmasi cenderung menurun.

Menurut Badan Koordinasi Penanaman Modal (BKPM), Investasi asing pada sektor farmasi dinilai kurang menggairahkan. Hal ini selain disebabkan oleh adanya Peraturan Menteri Kesehatan (Permenkes) Nomor 1010/MENKES/PER/XI/2008 Tahun 2008 tentang Registrasi Obat. Penyebab lain adalah infrastuktur yang belum mendukung. Lokasi pusat produksi barang farmasi di Indonesia masih terpisah jauh dari lokasi pengirimannya, sehingga menambah beban logistik. Biaya logistik yang mahal sehingga banyak investor harus berpikir ulang untuk berinvestasi di sektor farmasi Indonesia.

Rasio keuangan dapat digunakan untuk mengetahui gambaran tentang perkembangan keuangan suatu perusahaan, dapat dilihat dari interpretasi atau analisa terhadap data keuangan dari suatu perusahaan, dan data keuangan tersebut tercermin dari laporan keuangan. Rasio Likuiditas dapat menunjukkan kemampuan perusahaan dalam memenuhi kewajiban atau membayar utang jangka pendeknya. Dengan kata lain, rasio likuiditas adalah rasio yang dapat digunakan untuk mengukur sampai seberapa jauh tingkat kemampuan perusahaan dalam melunasi kewajiban jangka pendeknya yang akan segera jatuh tempo (Hery, 2016). Rasio Profitabilitas atau rentabilitas merupakan rasio yang menunjukkan kemampuan perusahaan dalam mencetak laba (Hantono, 2017)

Disamping bertujuan untuk mengetahui kemampuan perusahaan dalam menghasilkan laba selama periode tertentu, rasio ini juga bertujuan untuk mengukur tingkat efektivitas manajemen dalam menjalankan operasional perusahaan (Hery, 2016). Penelitian ini bertujuan untuk mengetahui, menganalisis, dan menjelaskan pengaruh Current Ratio, Return On Asset dan Nilai Tukar Rupiah baik secara parsial maupun simultan terhadap Harga Saham pada Sub Sektor Perusahaan Farmasi yang terdaftar di Bursa Efek Indonesia Tahun 2014-2018.

\section{Current Ratio}

current ratio menunjukkan jumlah kewajiban lancar yang dijamin pembayarannya oleh aktiva lancar. Semakin tinggi hasil perbandingan aktiva lancar dengan kewajiban lancar, semakin tinggi kemampuan perusahaan untuk menutupi kewajiban jangka pendeknya.(Hantono, 2017)

\section{Return On Assets}

Return on Assets adalah rasio yang menunjukkan tingkat pengembalian bisnis dari seluruh investasi yang telah dilakukan. (Hantono, 2017)

\section{Nilai Tukar Rupiah}

Nilai tukar adalah harga suatu mata uang terhadap mata uang lainnya atau nilai tukar dari suatu mata uang terhadap nilai mata uang lainnya. Kenaikan nilai tukar mata uang dalam negeri disebut apresiasi atas mata uang asing. Penurunan nilai tukar uang dalam negeri disebut depresiasi atas mata uang asing. (Mu'addab, 2011)

\section{Harga Saham}

Harga saham adalah satuan harga yang diperdagangkan di bursa efek, dalam transaksi harian maupun bulanan harga saham sering dicatat berdasarkan perdagangan terakhir atau sering disebut dengan harga penutupan. (Anoraga, 2006)

\section{METODE PENELITIAN}

Jenis penelitian ini adalah penelitian kuantitatif dengan data sekunder dan metode penelitian yang digunakan dalam penelitian ini adalah metode deskriptif verifikatif. Populasi dalam penelitian ini adalah Harga Saham yang diterbitkan oleh sub sektor perusahaan Farmasi yang terdaftar di Bursa Efek Indonesia (BEI) dalam periode tahun 2014 - 2018 yaitu sebanyak 11 perusahaan, berdasarkan kriteria yang telah ditentukan diperoleh 8 perusahaan sampel yaitu: DVLA, INAF, KAEF, KLBF, MERK, PYPA, SIDO, TSPC. Proksi variabel dalam penelitian ini dapat dilihat sebagai berikut.

Tabel 1. Variabel Penelitian

\begin{tabular}{|c|l|l|l|}
\hline No & Variabel & \multicolumn{1}{|c|}{ Pengukuran } & Skala \\
\hline 1 & $\begin{array}{l}\text { Current } \\
\text { Ratio }\end{array}$ & Aktiva lancar/Utang lancar & Rasio \\
\hline 2 & $\begin{array}{l}\text { Return On } \\
\text { Assets }\end{array}$ & $\begin{array}{l}\text { Laba bersih setelah pajak/ } \\
\text { Total Aktiva }\end{array}$ & Rasio \\
\hline 3 & $\begin{array}{l}\text { Nilai } \\
\text { Tukar } \\
\text { Rupiah }\end{array}$ & Kurs jual + Kurs beli / 2 & Rasio \\
\hline 4 & $\begin{array}{l}\text { Harga } \\
\text { Saham }\end{array}$ & $\begin{array}{l}\text { Harga pada saat penutupan } \\
\text { akhir tahun 2014 - 2018 }\end{array}$ & Rasio \\
\hline
\end{tabular}

Sumber: dari beberapa sumber

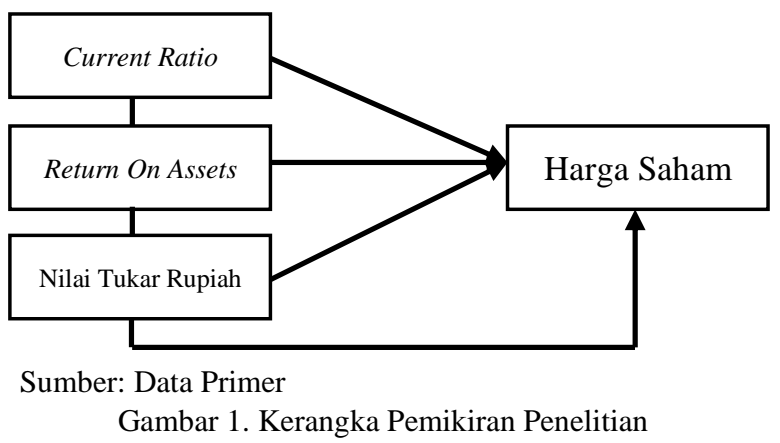


$\mathrm{H} 1: C R$ berpengaruh terhadap Harga Saham $\mathrm{H} 2: R O A$ berpengaruh terhadap Harga Saham H3 :NTR berpengaruh terhadap Harga Saham

$\mathrm{H} 4: C R, R O A, \mathrm{NTR}$ berpengaruh simultan terhadap Harga Saham

\section{Uji Asumsi Klasik}

Uji asumsi klasik digunakan untuk menguji asumsi-asumsi regresi linear yang bertujuan untuk menghindari bias dalam analisis data serta kesalahan spesifikasi (misspecification) model regresi yang digunakan. Dalam penelitian ini akan menggunakan uji normalitas dengan kolmogorov smirnov, uji multikolinearitas, uji glejser, dan uji autokorelasi.

\section{Analisis Regresi Linier Berganda}

Analisis regresi berganda adalah analisis yang dilakukan terhadap satu variabel terikat dan dua atau lebih variabel bebas. Model persamaanya adalah:

\section{Uji Hipotesis}

$$
Y=\alpha+\beta_{1} X_{1}+\beta_{2} X_{2}+\beta_{3} X_{3}+e
$$

Pengujian Hipotesis adalah prosedur yang didasarkan pada bukti sampel yang dipakai untuk menentukan apakah hipotesis merupakan suatu pernyataan yang wajar dan oleh karenanya tidak ditolak, atau hipotesis tersebut tidak wajar dan oleh karena itu harus ditolak.

\section{Koefisien Determinasi R2}

Koefisien determinasi digunakan untuk mengukur seberapa jauh kemampuan model dalam menerangkan variasi-variabel dependennya.

\section{HASIL DAN PEMBAHASAN}

Tabel 2. Hasil Uji Statistik Deskriptif

\begin{tabular}{|l|r|r|r|r|r|}
\hline & \multicolumn{1}{|c|}{ Des CRiptive Statistics } \\
\hline $\begin{array}{l}\text { CURRENT } \\
\text { RATIO [X1] }\end{array}$ & 40 & 1,04 & 10,30 & 3,2660 & 2,22625 \\
\hline $\begin{array}{l}\text { RETURN ON } \\
\text { ASSETS [X2] }\end{array}$ & 40 & $-3,02$ & 25,32 & 9,6268 & 7,01373 \\
\hline $\begin{array}{l}\text { NILAI TUKAR } \\
\text { RUPIAH [X3] }\end{array}$ & 40 & 12440 & 14481 & 13540,00 & 667,392 \\
\hline $\begin{array}{l}\text { HARGA SAHAM } \\
\text { [Y] }\end{array}$ & 40 & 112 & 9200 & 2373,30 & 2448,332 \\
\hline Valid N (listwise) & 40 & & & & Std. Deviation \\
\hline
\end{tabular}

Sumber: Output SPSS, data diolah peneliti 2020

Berdasarkan tabel 2. diatas jumlah data $(\mathrm{N})$ dalam penelitian ini yaitu sebanyak 40 data dari 8 perusahaan farmasi tahun 2014-2018. Variabel dependen pada penelitian ini adalah Harga Saham dan untuk variabel independen nya adalah Current Ratio, Return On Assets dan Nilai Tukar Rupiah. Dengan analisis deskriptif sebagai berikut:

1. Current Ratio memiliki rata-rata sebesar 3,2660 dengan standar deviasi sebesar 2,22625. Nilai current ratio tertinggi yaitu sebesar 10,30, sedangkan nilai current ratio terendah yaitu sebesar 1,04. Current Ratio memiliki mean sebesar 3,2660 dengan standar deviasi sebesar 2,22625 yang artinya nilai mean > standar deviasi, sehingga menunjukkan hasil yang cukup baik dan dapat dikatakan penyebaran datanya normal dan tidak menyebabkan bias

2. Return On Assets memiliki rata-rata sebesar 9,6268 dengan standar deviasi sebesar 7,01373 . Nilai return on asset tertinggi yaitu sebesar 25,32, sedangkan nilai return on asset terendah yaitu sebesar -3,02. Return On Assets memiliki mean sebesar 9,6268 dengan standar deviasi sebesar 7,01373 yang artinya mean > standar deviasi, sehingga menunjukkan hasil yang cukup baik dan dapat dikatakan penyebaran datanya normal dan tidak menyebabkan bias.

3. Nilai Tukar Rupiah memiliki rata-rata sebesar 13540,00 dengan standar deviasi sebesar 667,392 . Nilai tukar rupiah tertinggi yaitu sebesar 14.481 pada tahun 2014, sedangkan nilai tukar rupiah terendah yaitu sebesar 12.440 pada tahun 2018. Nilai Tukar Rupiah memiliki rata-rata sebesar 13540,00 dengan standar deviasi sebesar 667,392 yang artinya nilai mean > standar deviasi, sehingga menunjukkan hasil yang cukup baik dan dapat dikatakan penyebaran datanya normal dan tidak menyebabkan bias.

4. Harga Saham memiliki rata-rata sebesar 2373,30 dengan standar deviasi sebesar 2448,332. Nilai harga saham tertinggi yaitu sebesar 9.200, sedangkan nilai harga saham terendah yaitu sebesar 112. Harga Saham memiliki rata-rata sebesar 2373,30 dengan standar deviasi sebesar 2448,332 yang artinya nilai mean < standar deviasi, sehingga menunjukkan hasil yang kurang baik dan dapat dikatakan penyebaran datanya tidak normal dan menyebabkan bias.

Tabel 3. Hasil Uji Kolmogorov Smirnov

\begin{tabular}{|c|c|c|}
\hline \multicolumn{3}{|c|}{ One-Sample Kolmogorov-Smirnov Test } \\
\hline & & $\begin{array}{c}\text { Unstandardized } \\
\text { Residual }\end{array}$ \\
\hline \multicolumn{2}{|l|}{$\mathrm{N}$} & 40 \\
\hline \multirow{2}{*}{$\begin{array}{l}\text { Normal } \\
\text { Parameters }{ }^{\mathrm{a}, \mathrm{b}}\end{array}$} & Mean & $0 \mathrm{E}-7$ \\
\hline & Std. Deviation & 1919,88293560 \\
\hline \multirow{3}{*}{\begin{tabular}{|l} 
Most \\
Extreme \\
Differences
\end{tabular}} & Absolute & ,187 \\
\hline & Positive &, 187 \\
\hline & Negative &,- 126 \\
\hline \multicolumn{2}{|c|}{ Kolmogorov-Smirnov Z } & 1,181 \\
\hline \multicolumn{2}{|c|}{ Asymp. Sig. (2-tailed) } &, 123 \\
\hline
\end{tabular}

Berdasarkan tabel 3. diatas hasil uji OneSample Kolmogorov Smirnov Test diperoleh data Asymp.Sig. (2-tailed) atas variabel X1 (Current Ratio), X2 (Return On Asset), X3 (Nilai Tukar Rupiah) dan Y (Harga Saham) sebesar 0,123. Karena $0.123>0.05$, maka dapat disimpulkan bahwa data penelitian ini berdistribusi normal. 
Tabel 4. Hasil Uji Multikolinearitas

\begin{tabular}{|c|c|c|}
\hline \multicolumn{3}{|c|}{ Coefficients $^{a}$} \\
\hline \multirow[t]{2}{*}{ Model } & \multicolumn{2}{|c|}{ Collinearity Statistics } \\
\hline & Tolerance & $\mathrm{VIF}$ \\
\hline CURRENT RATIO [X1] &, 703 & 1,423 \\
\hline RETURN ON ASSETS [X2] & ,727 & 1,375 \\
\hline NILAI TUKAR RUPIAH [X3] &, 960 & 1,041 \\
\hline
\end{tabular}

a. Dependent Variable: HARGA SAHAM [Y]

Sumber: Output SPSS, data diolah peneliti 2020

Berdasarkan tabel 4. diatas hasil uji multikolinearitas diketahui bahwa nilai VIF untuk variabel $C R$ (X1), ROA (X2) dan Nilai Tukar Rupiah (X3) hanya ada di kisaran 1,041 sampai 1,423 yang berarti $<10,00$ dan nilai Tolerance untuk variabel $C R$ (X1), ROA (X2) dan Nilai Tukar Rupiah (X3) > 0,10 maka dapat disimpulkan bahwa data tidak terjadi multikolinearitas antar variabel bebas.

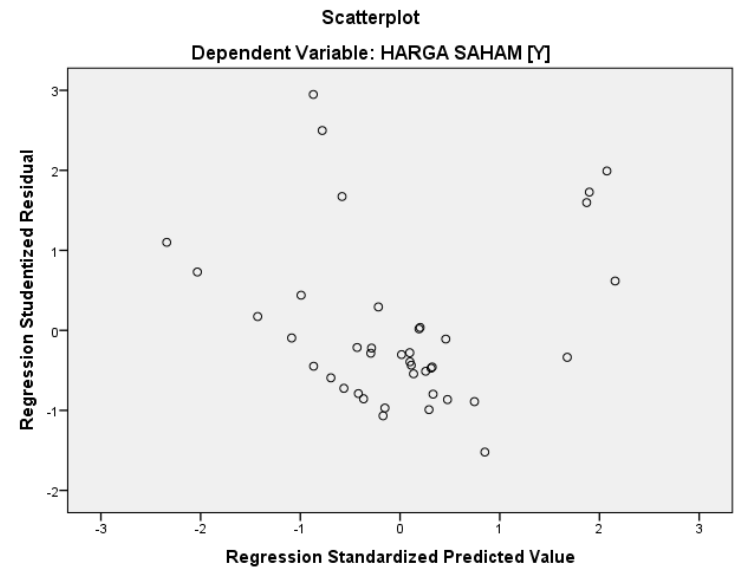

Sumber: Output SPSS, data diolah peneliti 2020

Gambar 2. Hasil Uji Heteroskedastisitas

Berdasarkan Gambar 2. diatas terlihat bahwa titik-titik pola tidak terbentuk secara jelas bahkan terlihat saling menyebar satu sama lain. Maka disimpulkan bahwa penelitian ini tidak terjadi heteroskedastisitas. Namun untuk memperkuat maka penelitian ini menggunakan uji glejser, apabila nila sig > 0.05 maka data tidak terjadi heteroskedastisitas. Berikut adalah tabelnya.

Tabel 5. Hasil Uji Glejser

\begin{tabular}{l} 
Coefficients ${ }^{\mathbf{a}}$ \\
\begin{tabular}{|l|l|l|}
\hline \multicolumn{2}{|c|}{ Model } & Sig. \\
\multicolumn{2}{|c|}{} & \\
\hline \multirow{2}{*}{1} & (Constant) &, 372 \\
\cline { 2 - 3 } & CURRENT RATIO [X1] &, 179 \\
\cline { 2 - 3 } & RETURN ON ASSETS [X2] &, 962 \\
\cline { 2 - 3 } & NILAI TUKAR RUPIAH [X3] &, 659 \\
\hline
\end{tabular} \\
\hline
\end{tabular}

Sumber: Output SPSS, data diolah peneliti 2020

Berdasarkan tabel 5. diatas, dapat diketahui bahwa masing-masing variabel memiliki hasil sig > 0,05 hal ini berarti bahwa data tidak terjadi heteroskedastisitas
Tabel 6. Hasil Uji Autokorelasi

\begin{tabular}{|c|c|}
\hline \multicolumn{2}{|c|}{ Model Summary ${ }^{b}$} \\
\hline Model & Durbin-Watson \\
\hline 1 & 1,047 \\
\hline
\end{tabular}

a. Predictors: (Constant), NILAI TUKAR RUPIAH [X3], RETURN

ON ASSETS [X2], CURRENT RATIO [X1]

b. Dependent Variable: HARGA SAHAM [Y]

Sumber: Output SPSS, data diolah peneliti 2020

Berdasarkan tabel 6. diperoleh nilai DW 1,047 yang berarti nilai itu berada di antara -2 hingga +2 dapat disimpulkan bahwa data penelitian ini tidak terjadi autokorelasi.

Tabel 7. Hasil Uji Regresi Linier Berganda

\begin{tabular}{|c|c|c|}
\hline \multicolumn{3}{|c|}{ Coefficients $^{a}$} \\
\hline \multirow{2}{*}{\multicolumn{2}{|c|}{ Model }} & Unstandardized Coefficients \\
\hline & & $\mathrm{B}$ \\
\hline \multirow{4}{*}{1} & (Constant) & 6848,536 \\
\hline & CURRENT RATIO [X1] & $-715,954$ \\
\hline & RETURN ON ASSETS [X2] & 219,585 \\
\hline & NILAI TUKAR RUPIAH [X3] &,- 314 \\
\hline
\end{tabular}

Sumber: Output SPSS, data diolah peneliti 2020

1. Nilai konstansta $\alpha$ sebesar 6848,536 menunjukkan tanda positif yang berarti bahwa jika tidak ada perubahan dari variabel independen yaitu $C R$ (X1), ROA (X2) dan Nilai Tukar Rupiah (X3) maka variabel dependen yaitu Harga Saham (Y) tetap bernilai 6848,536

2. Variabel Current Ratio (CR) memiliki arah koefisien regresi yang negatif, hal ini berarti adanya hubungan yang tidak searah antara Current Ratio (CR) dan Harga Saham (Y). Nilai koefisien sebesar $-715,954$ berarti apabila ada kenaikan $1 \%$ pada Current Ratio $(C R)$ maka akan menyebabkan penurunan sebesar 715,954 pada Harga Saham (Y). Begitu pula sebaliknya, dengan ketentuan variabel lain tetap.

3. Variabel Return On Assets (ROA) memiliki arah koefisien regresi yang positif, hal ini berarti adanya hubungan searah antara Return On Assets (ROA) dan Harga Saham (Y). Nilai koefisien sebesar 219,585 berarti apabila ada kenaikan $1 \%$ pada Return On Assets (ROA) maka akan menyebabkan kenaikan pula sebesar 219,585 pada Harga Saham (Y). Begitu pula sebaliknya, dengan ketentuan variabel lain tetap

4. Variabel Nilai Tukar Rupiah memiliki arah koefisien regresi yang negatif, hal ini berarti adanya hubungan yang tidak searah antara Nilai Tukar Rupiah dan Harga Saham (Y). Nilai koefisien sebesar $-0,314$ berarti apabila ada kenaikan sebesar $1 \%$ pada Nilai Tukar Rupiah maka akan menyebabkan penurunan sebesar 
0,314 pada Harga Saham (Y). Begitu pula sebaliknya, dengan ketentuan variabel lain tetap.

Tabel 8. Hasil Uji Parsial (t)

\begin{tabular}{|} 
Model Coefficients $^{\mathrm{a}}$ \\
\begin{tabular}{|c|l|r|c|}
\hline \multicolumn{2}{|c|}{} & $\mathrm{t}$ & Sig. \\
\hline \multirow{4}{*}{1} & & \\
\cline { 2 - 4 } & (Constant) & 1,018 &, 315 \\
\cline { 2 - 4 } & CURRENT RATIO [X1] & $-4,175$ &, 000 \\
\cline { 2 - 4 } & RETURN ON ASSETS [X2] & 4,104 &, 000 \\
\cline { 2 - 4 } & NILAI TUKAR RUPIAH [X3] &,- 642 &, 525 \\
\hline
\end{tabular} \\
a. Dependent Variable: HARGA SAHAM [Y]
\end{tabular}

Sumber: Output SPSS, data diolah peneliti 2020

Berdasarkan tabel 8. diatas, terdapat thitung untuk masing-masing variabel. Penelitian ini menggunakan tingkat signifikansi 5\% dan diperoleh $\mathrm{t}_{\text {tabel }}=\mathrm{t}(\mathrm{a} / 2 ; \mathrm{n}-\mathrm{k}-1)=\mathrm{t}(0.025 ; 36)=2.028$. Ket: $\mathrm{n}=40, \mathrm{k}=3$. Maka hasil pengujiannya adalah sebagai berikut:

1. Pengaruh Current Ratio $(C R)$ terhadap Harga Saham

Berdasarkan tabel 8 nilai thitung sebesar $-4,175$ jika dibandingkan dengan $t_{\text {tabel }}$ sebesar 2,028 yang berarti nilai $t_{\text {hitung }}>$ nilai $t_{\text {tabel }}$. Serta diperoleh nilai signifikan sebesar $0,000<$ dari 0,05. Maka $\mathrm{H}_{\mathrm{O}}$ ditolak dan $\mathrm{H}_{1}$ diterima.

2. Pengaruh Return On Assets (ROA) terhadap Harga Saham

Berdasarkan tabel 8 nilai $t_{\text {hitung }}$ sebesar 4,104 jika dibandingkan dengan $t_{\text {tabel }}$ sebesar 2,028 yang berarti nilai $t_{\text {hitung }}>$ nilai $t_{\text {tabel }}$. Serta diperoleh nilai signifikan sebesar $0,000<$ dari 0,05 . Maka $\mathrm{H}_{\mathrm{O}}$ ditolak dan $\mathrm{H}_{2}$ diterima.

3. Pengaruh Nilai Tukar Rupiah terhadap Harga Saham

Berdasarkan tabel 8 nilai $t_{\text {hitung }}$ sebesar 0,642 jika dibandingkan dengan $t_{\text {tabel }}$ sebesar 2,028 yang berarti nilai $t_{\text {hitung }}<$ nilai $t_{\text {tabel }}$. Serta diperoleh nilai signifikan sebesar $0,525>$ dari 0,05 . Maka $\mathrm{H}_{\mathrm{O}}$ diterima dan $\mathrm{H}_{3}$ ditolak.

Tabel 9.Hasil Uji Simultan (f)

Model
\begin{tabular}{|l|r|r|}
\hline \multicolumn{1}{|c|}{ ANOVAa } \\
\hline Regression & 7,515 &, $000^{\mathrm{b}}$ \\
& & \\
\hline
\end{tabular}
a. Dependent Variable: HARGA SAHAM [Y]
b. Predictors: (Constant), NILAI TUKARR RUPIAH [X3], RETURN
ON ASSETS [X2], CURRENT RATIO [X1]
Sumber: Output SPSS, data diolah peneliti 2020

Berdasarkan tabel 9. diatas, sudah terdapat $\mathrm{f}_{\text {hitung untuk semua variabel. Penelitian ini }}$ menggunakan tingkat signifikansi $5 \%$ dan diperoleh $\mathrm{f}_{\text {tabel }}=\mathrm{F}(\mathrm{k} ; \mathrm{n}-\mathrm{k})=\mathrm{F}(3 ; 37)=2.86$. Ket: $\mathrm{n}=40, \mathrm{k}=3$. Maka hasil pengujiannya adalah sebagai berikut

1. Pengaruh Current Ratio, Return On Assets, Nilai

Tukar Rupiah Secara Bersama-sama terhadap harga saham

Berdasarkan tabel 9 nilai $f_{\text {hitung }}$ sebesar 7,515 jika dibandingkan dengan $\mathrm{f}_{\text {tabel }}$ sebesar 2,86 yang berarti nilai $f_{\text {hitung }}>$ nilai $f_{\text {tabel}}$, serta diperoleh nilai signifikansi sebesar $0,000<0,05$. Maka Ho ditolak dan h4 diterima.

Tabel 10. Hasil Uji Koefisien Determinasi R ${ }^{2}$

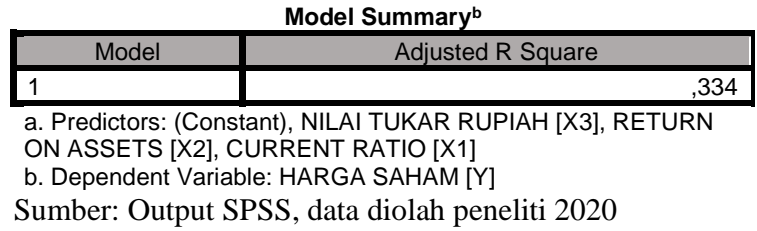

Berdasarkan tabel 10. didapat nilai Adjusted $\mathrm{R}$ square sebesar 0,334, hal ini berarti pengaruh Current Ratio, Return On Assets dan Nilai Tukar Rupiah secara bersama-sama terhadap Harga Saham sebesar $33,4 \%$, sisanya $66,6 \%$ dipengaruhi oleh variabel lain yang tidak diteliti dalam penelitian ini.

\section{HASIL DAN PEMBAHASAN}

\section{Pengaruh Current Ratio Terhadap Harga Saham}

Berdasarkan hasil pengujian dapat disimpulkan bahwa Current Ratio (CR) berpengaruh negatif dan signifikan terhadap harga saham. Hal ini sesuai dengan hipotesis yang telah dibuat, Maka kesimpulannya Ho ditolak dan $\mathrm{H} 1$ diterima.

Penelitian ini bertentangan dengan dengan hasil penelitian (Raghilia Amanah, Dwi Atmanto, 2014) yang menyatakan Current Ratio berpengaruh positif signifikan terhadap harga saham. Namun penelitian ini sejalan dengan (Ni Wayan Nurani Wijanti, 2013) yang menyatakan bahwa Current Ratio (CR) berpengaruh negatif signifikan terhadap Harga Saham.

Current Ratio yang rendah tidak selalu berarti buruk, hutang yang besar namun dikelola dengan baik misalnya digunakan untuk keperluan meningkatkan produktivitas perusahaan sehingga laba perusahaan menjadi lebih produktif. Current Ratio farmasi berada di kisaran 2 hal itu masih sesuai dengan standar industri yang ditetapkan. Oleh karena itu investor masih tetap percaya menanamkan modalnya pada perusahaan walau current ratio yang ditunjukkan rendah sehingga harga saham perusahaan tersebut pun ikut meningkat.

\section{Pengaruh Return On Assets Terhadap Harga Saham}

Berdasarkan hasil pengujian dapat disimpulkan bahwa Return On Assets (ROA) berpengaruh positif dan signifikan terhadap harga saham. Hal ini sesuai dengan hipotesis yang telah dibuat, Maka kesimpulannya Ho ditolak dan H2 diterima.

Penelitian ini bertentangan dengan hasil penelitian (Albertha W Hutapea, Ivonne S Saerang, 2017) yang menyatakan Return On Assets (ROA) tidak berpengaruh signifikan terhadap harga saham. Namun penelitian ini sejalan dengan (Vera Ch O Manoppo, Bernhard Tewal, 2017) yang menyatakan 
bahwa Return On Assets (ROA) berpengaruh positif terhadap Harga Saham.

Return On Assets menggambarkan laba yang dihasilkan perusahaan atas aktiva yang tersedia di dalam perusahaan. semakin tinggi ROA maka semakin baik produktivitas aset dalam memperoleh keuntungan bersih. Perusahaan yang memiliki tingkat $R O A$ yang baik, membuat investor tertarik untuk menanamkan modalnya sehingga hal tersebut membuat harga saham perusahaan diminati lalu akan mengakibatkan peningkatan harga saham perusahaan 3. Pengaruh Nilai Tukar Rupiah Terhadap Harga Saham

Berdasarkan hasil pengujian dapat disimpulkan bahwa Nilai Tukar Rupiah tidak berpengaruh dan tidak signifikan terhadap harga saham. Hal ini tidak sesuai dengan hipotesis yang telah dibuat, Maka kesimpulannya Ho diterima dan H3 ditolak.

Penelitian ini bertentangan dengan hasil penelitian (Zainuddin Iba, 2012) yang menyatakan Nilai tukar Rupiah berpengaruh positif dan signifikan terhadap harga saham. Namun penelitian ini sejalan dengan (Tana Ahmad Permana, Edhi Asmirantho, 2017) yang menyatakan bahwa Nilai Tukar Rupiah tidak berpengaruh terhadap Harga Saham.

Perusahaan yang memiliki kemampuan dengan baik dalam hal mengelola keuangannya dan memiliki strateginya tersendiri hal tersebut menyebabkan perusahaan mampu mengurangi dampak yang disebabkan oleh depresiasi nilai tukar rupiah. Kemampuan perusahaan tersebut akan membuat investor tetap percaya walaupun kondisi rupiah sedang mengalami depresiasi. Beberapa strategi perusahaan farmasi yaitu, selalu menyiapkan uang cash dalam bentuk dollar AS, membeli bahan baku dalam jumlah yang besar untuk stok beberapa bulan kedepan, menerapkan kebijakan menaikkan harga produk kesehatan yang meliputi obat bebas dan minuman nutrisi, memakai bahan baku alternatif, dan melakukan kontrak pembelian bahan baku dengan harga dan dalam jangka waktu tertentu.

4. Pengaruh Current Ratio, Return On Assets dan Nilai Tukar Rupiah Terhadap Harga Saham

Berdasarkan hasil pengujian dapat disimpulkan bahwa Current Ratio, Return On Assets dan Nilai Tukar Rupiah secara bersama-sama berpengaruh dan signifikan terhadap Harga Saham. Hal ini sesuai dengan hipotesis yang telah dibuat, Maka Ho ditolak dan h4 diterima.

Dari hasil koefisien determinasi $\left(\mathrm{R}^{2}\right)$ pada tabel 10 diperoleh nilai Adjusted R Square sebesar 0,334 atau sama dengan $33,4 \%$ yang menunjukkan bahwa secara bersama-sama current ratio, return on assets, dan nilai tukar rupiah mampu menjelaskan dan memberikan pengaruh terhadap harga saham sebesar $33,4 \%$ dan sisanya $66,6 \%$ dijelaskan atau dipengaruhi oleh faktor lain yang tidak diuji dalam penelitian ini.

Penelitian ini sejalan dengan (Marvina, Maya Syafriana Effendi, 2020) yang menyatakan bahwa Current Ratio, Return On Assets dan Nilai Tukar Rupiah memiliki pengaruh yang signifikan terhadap Harga Saham.

\section{KESIMPULAN}

Berdasarkan hasil penelitian yang telah dilakukan, maka kesimpulannya adalah:

1. Current Ratio (CR) berpengaruh negatif dan signifikan terhadap harga saham

2. Return On Assets (ROA) berpengaruh positif dan signifikan terhadap harga saham.

3. Nilai Tukar Rupiah tidak berpengaruh dan tidak signifikan terhadap Harga Saham.

4. Secara simultan, Current Ratio (CR), Return On Assets (ROA) dan Nilai Tukar Rupiah berpengaruh dan signifikan terhadap Harga Saham..

\section{REFERENSI}

Albertha W Hutapea, Ivonne S Saerang, J. E. T. (2017). Pengaruh Return On Assets, Net Profit Margin, Debt To Equity Ratio, Dan Total Assets Turnover Terhadap Harga Saham Industri Otomotif Dan Komponen Yang Terdaftar Di Bursa Efek Indonesia. Jurnal EMBA, 5(2), 541-552.

Anoraga, P. (2006). Pengantar Pasar Modal. Rineka Cipta.

Hantono. (2017). Konsep analisa laporan keuangan dengan pendekatan rasio dan spss. Deepublish.

Hery. (2016). Analisis Laporan Keuangan Integrated and comprehensive edition. Grasindo.

Marvina, Maya Syafriana Effendi, S. (2020). Pengaruh Current Ratio $(C R)$, Return On Assets (ROA), Price To Book Value (PBV), Dan Nilai Tukar Terhadap Harga Saham Pada Perusahaan Perdagangan Eceran Yang Tercatat Di Bursa Efek Indonesia Periode Tahun 2010 2017. IKRA-ITH Ekonomika, 3(1), 92-101. https://journals.upiyai.ac.id/index.php/IKRAITHEKONOMIKA/article/view/641

Mu'addab, H. (2011). Pasar valuta asing (Foreign Exchange Market). Garuda Mas Sejahtera.

Ni Wayan Nurani Wijanti, I. B. P. S. (2013). Pengaruh Likuiditas, Efektivitas Aktiva dan Ukuran Perusahaan terhadap Kebijakan Dividen dan Harga Saham. E-Jurnal Manajemen Universitas Udayana, 2(12), 253958. https://doi.org/10.31219/osf.io/ct85h

Raghilia Amanah, Dwi Atmanto, D. F. A. (2014). Pengaruh Rasio Likuiditas Dan Rasio Profitabilitas Terhadap Harga Saham (Studi pada Perusahaan Indeks LQ45 Periode 20082012). Jurnal Administrasi Bisnis S1 Universitas Brawijaya, 12(1), 83167.

Tana Ahmad Permana, Edhi Asmirantho, C. (2017). 
Pengaruh Suku Bunga, Nilai Tukar, Profitabilitas, Likuiditas, dan Solvabilitas terhadap Harga Saham pada Perusahaan BUMN yang terdaftar di Bursa Efek Indonesia tahun 2013-2015. Jurnal Online Mahasiswa (JOM) Bidang Manajemen.

Vera Ch O Manoppo, Bernhard Tewal, A. B. H. J. (2017). Pengaruh Current Ratio, DER, ROA DAN NPM Terhadap Harga Saham Pada Perusahaan Food And Beverages Yang
Terdaftar Di BEI Periode 2013-2015. Jurnal EMBA, 5(2), 1813-1822. https://doi.org/10.35794/emba.v5i2.16399

Zainuddin Iba, A. W. (2012). Pengaruh Inflasi, Suku Bunga SBI, Nilai Tukar Rupiah Terhadap USD, Profitabilitas, Dan Pertumbuhan Aktiva Terhadap Harga Saham Perusahaan Pembiayaan Di Bursa Efek Indonesia. Jurnal Kebangsaan, 1(1), 1-6. 